\title{
Equine Embryo Sexing - a Case Study of its applicability in Romania
}

\author{
Melania I. CRIȘAN, Iancu A. MORAR*, Mihai CENARIU, Aurel DAMIAN, Cristian CRECAN, Emoke PALL, \\ Cosmin PESTEAN and Ioan S. GROZA \\ Faculty of Veterinary Medicine, University of Agricultural Sciences and Veterinary Medicine of Cluj- \\ Napoca, Romania \\ *catedra1mv@yahoo.com
}

Bulletin UASVM Veterinary Medicine 72(1) / 2015,

Print ISSN 1843-5270; Electronic ISSN 1843-5378

doi:10.15835/buasvmcn-vm: 11462

\begin{abstract}
The interest of sex determination in embryos has an economical and research implication. This method is directly related to the embryo transfer method, which nowadays is considered to be an industry, in both equine and bovine. The purpose of this work was to evaluate the applicability of equine embryo sexing using the polymerase chain reaction (PCR) and to decide if this method is affordable for Romania and yields good results. Five equine embryos have been obtained by natural breeding using transcervical uterine lavage with Ringer Lactate on 6.5 or 7 days. The DNA extraction was performed by using proteinase K and the DNA was quantified by spectrophotometry. Three sets of primers have been used. The double nested PCR was performed, followed by electrophoresis of the amplified samples. From the five embryos obtained, three samples presented a single 445 bp DNA band and no SRY band and they were considered to be females. In two cases, the $445 \mathrm{bp}$ was accompanied by the SRY-1 217 bp and SRY-2 $121 \mathrm{bp}$ band, thus being considered to come from male embryos. The embryo biopsy was done in 2 embryos and one biopsied embryo was transferred to a recipient mare. The transfer of the biopsied embryo did not succeed. PCR is suitable for sexing preimplantation equine embryos, but still in order to perform this type of activity at a commercial level, the infrastructure and the development of Equine Reproduction centres it's mandatory.
\end{abstract}

Keywords: embryo sexing, equine, PCR

\section{INTRODUCTION}

The interest of sex determination in embryos has an economical and research implication. This method is directly related to the embryo transfer method, which nowadays is considered to be an industry, in both equine and bovine. Of course, in bovine the number of worldwide transferred embryos is much larger, 500.000 embryos yearly (Cenariu, 2012) compared to equines, 40.833 in 2011 (Stroud, 2012). This difference is related to the economic interest and also to the fact that in cows, superovulation can be induced with very good results, compared to mares. One of the major objectives of large animal breeders is to be able to choose the sex of the offspring. In horses, the male sex is preferred in Thoroughbreds racing horses (Chezum and Wimmer, 1997) and the female sex in Polo horses (Panarace et al., 2013; Hererra et al., 2014). A number of invasive and non-invasive techniques of embryo sexing have been developed and tested so far. The success and application of embryo sexing became possible only when the biotechnologies in reproduction had developed, especially the artificial insemination and the embryo transfer (Mara L et al., 2004; Cenariu, 2012). For horse breeders, the importance of sex of the foals it is based on individual consideration and it is in direct correlation with the future sportive activity of the animal. (Aurich and Schneider, 2014). In mares the genetic diagnosis of the embryo it is very valuable due to the costs of the pregnancy

The purpose of this paper is to evaluate the applicability of equine embryo sexing using the polymerase chain reaction (PCR) and to decide if 
this method is affordable for Romania and yields good results.

\section{MATERIALS AND METHODS}

The study was conducted on 10 mares belonging to horse owners nearby Cluj County. Five equine embryos were obtained by natural breeding. The practical research was performed at the Department of Veterinary Reproduction, Obstetrics and Gynecology of the Faculty of Veterinary Medicine, Cluj-Napoca in collaboration with free-practitioners veterinarians, during February-June 2015. The embryos have been non-surgically collected, using transcervical uterine lavage with Ringer Lactate on 6.5 or 7 days. The day of the ovulation was considered day 0. Estrous cycles were monitored using transrectal ultrasonography from February to June, 2015. Mares were administered 3,000 IU hCG (Chorulon $®$, Intervet/Schering-Plough, Millsboro, DE) i.v. The embryos were collected at 6,5 or 7 days after the ovulation.

The embryos have been morphologically evaluated at the stereomicroscope. In 2 cases, the biopsy was performed in order to collect a small number of blastomeres from the inner cell mass. In 3 cases the whole embryo was used for DNA extraction. We were interested in the identification of specific nucleotides that can be found only on Y chromosome. The DNA extraction was performed by using proteinase $\mathrm{K}$. The quantification of the DNA was done by spectrophotometry (Spectophotometer NanoDrop ND-1000®). A duplex nested PCR was used for amplification of the DNA using primers for sex chromosome linked-zinc finger protein genes (ZFx/ZFy; 445 $\mathrm{bp)}$. The sequence of these two primers was: upstream 5'-ATAATCACATGGAGAGCCACAAGCT-3, downstream5'-GCACTTCTTTGGTATCTGAGAAAGT - 3 (Cullingford, 2010). The second set of primers contained two pairs of primers for the equine-specific sex-determining region on the Y-chromosome (SRY-1 217 bp; SRY-2 121 bp), according to Cullingford, 2010. For the first pair (SRY-1) the sequence of the primers was: upstream 5'-ACAAACGGGAGGAGCGGTTA-3' and downstream 5'-CAGGGACTCTGAAGCCACCA-3'. For the second pair (SRY-2), the upstream was: 5' - CCATTCGGGTAACGTTGGCTA-3' and the downstream sequence was: 5'CAGGGACTCTGAAGCCACCA-3'. The specificity of the primers was tested on control blood samples $(n=8)$ coming from stallions $(n=4)$ and nonpregnant mares $(n=4)$.

The PCR was carried out on a total volume of $25 \mu \mathrm{L}$, composed of $2 \mu \mathrm{l}$ diluted DNA, $9 \mu \mathrm{L}$ Ultrapure water (Accu GENE® Molecular Biology Water, Lonza, Belgium), $10 \mu \mathrm{L}$ Supermix, MyTaq ${ }^{\mathrm{TM}}$ Red Mix (Bioline, USA) and $1 \mu \mathrm{l}(40 \mathrm{pmol})$ of the following primers (ZFx/ZFy-F; ZFx/ZFy-R; SRY-F1; SRY-R1). The amplification of the DNA was done by using a thermocycler Corbett Research ${ }^{\circledR}$ (QIAGEN, Netherlands) for 10 cycles. A second reaction $(1 \mu \mathrm{l}$ from the original reaction) was performed with the second pair of SRY-2 for 40 cycles. The amplification scheme consisted of initial denaturation at $95^{\circ} \mathrm{C}$ for 2 minutes, denaturation at $95^{\circ} \mathrm{C}$ for 45 seconds, primer annealing at $62^{\circ} \mathrm{C}$ for 45 seconds and primer extension at $72^{\circ} \mathrm{C}$ for 1 minute and the final extension at $72^{\circ} \mathrm{C}$ for 9 minutes. The electrophoresis of the amplified samples was performed in a $2 \%$ agarose gel stained with RedSafe Nucleic Acid Staining Solution ${ }^{\text {TM }}$ (iNtRon Biotechnology, Sangdaewon-Dong, Korea) for 1 hour at $110 \mathrm{~V}$. The results were visualized and photographed using UV light transilumination.

\section{RESULTS AND DISCUSSION}

The presence of ZFx/ZFy band confirms the presence of the equine DNA. The presence or absence of the SRY band confirmed the genetic sex of the embryo. In case of absence of this band, the embryo was classified as female. The presence of an SRY-1 and SRY-2 band confirmed the presence of a Y-specific DNA sequence and the embryo was classified as male (Fig. 1). The second one is more intense due to the amplification of the DNA for 40 cycles. A DNA ladder of 100-500 bp is situated in the left lane.

From the 5 embryos obtained, 3 had reached the morula stage and 2 were in the early blastocyst stage. After the amplification and gel electrophoresis of the 5 samples, 3 samples presented a single 445 bp DNA band and no SRY band and they were considered to be females. In 2 cases, the 445 bp was accompanied by the SRY- 1 $217 \mathrm{bp}$ band and SRY-2 $121 \mathrm{bp}$ band, thus being considered to come from male embryos. As for the quality of the embryos, 2 were transferable and were used for embryo biopsy, while 3 were not suited for this purpose. The embryo biopsy was successful in one embryo and the blastomeres were 


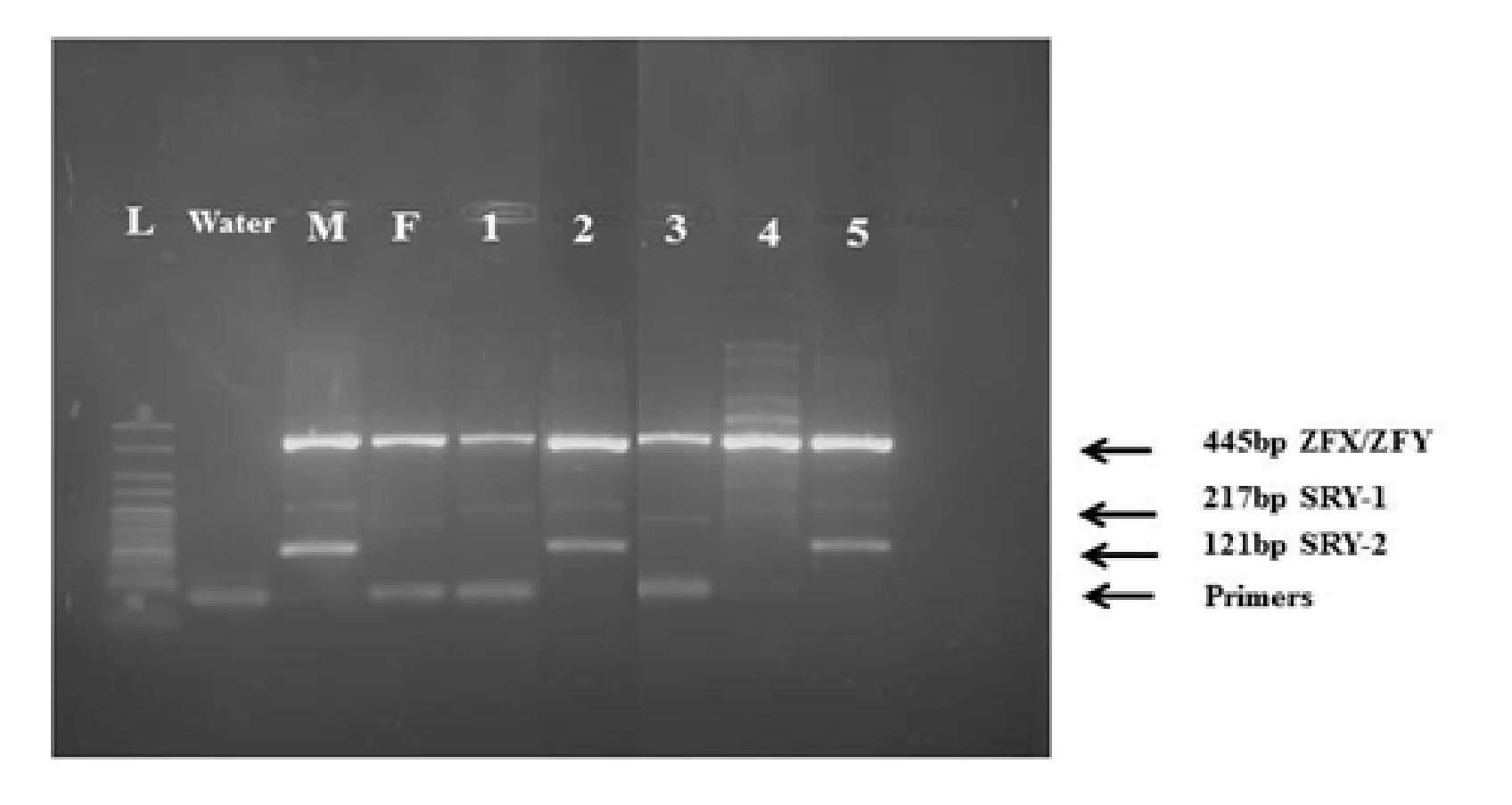

Fig. 1. Agarose gel obtained after the electrophoresis of 5 DNA samples:

1 and 5 represents male embryos, 2,3 and 4 represents female embryos

$(\mathrm{L}=$ ladder, water $=$ negative control, $1-5=$ the DNA samples, $\mathrm{F}=$ female control, $\mathrm{M}=$ male control $)$

collected in good conditions. After the biopsy the embryo was transferred to recipient mare, whose estrous cycle had previously been synchronized with the donor's mare. The pregnancy was evaluated by transrectal ultrasound and the mare was considered pregnant if the embryonic vesicle was present at 16 days. In our case, the embryo transfer did not succeed.

The PCR proved to be a useful and not very expensive method for determination of the genetic sex of the pre-implantation embryos. This method it is easy to perform and it requires low expenses for materials and equipment (Cenariu, 2011), but still is not applicable in the field because specialized laboratories with trained personnel is needed. The technique was firstly applied in 1985 by Karry Mullis and it was used for the first time in equine embryo sexing by Huhtinen et al. in 1997. In horses, the quantity of DNA harvested from biopsies is low and a double nested PCR is mandatory (Cullingford, 2010; Herrera et al., 2014). There are recent studies that evaluate and encourage equine embryo sexing by cell aspiration (Choi et al., 2010; Seidel et al., 2010; Troedsson et al., 2010; Choi et al., 2011; Hererra et al., 2012; Riera et al., 2012; Guignot et al., 2012; Jarazo et al.,
2013), but in Romania this is the first study of this type.

We have noticed that a huge limitation of the applicability of this study is related to the biopsy technique of the embryo. Another impediment in performing this method frequently is represented by the fact that most of the owners do not usually resort to this advanced diagnostic tool because of the cost of embryo transfer and logistical inconveniences.

\section{CONCLUSION}

This type of research is a premiere in Romania. It has been done on bovine (Cenariu, 2011) with good results. The PCR sexing method itself is not difficult to be performed and requests low expenses for materials and equipment, but the succes rate of sexed embryos' transfer it is depending on many factors such as the biopsy technique of the embryo and the logistics. In order to be able to offer this type of service, an Equine Reproduction center needs to be created, so that all the steps can be performed in the same location. Improvements of the biopsy technique are necessary to be made in the future in order to reduce the damage of the embryos and to be able to obtain higher pregnancy 
rates. With all these mentioned, we recommend and encourage the use of commercial PCR sexing kits for equine embryo sexing.

Acknowledgments. The research was made and this paper was published under the frame of European Social Found, Human Resources Development Operational Program 2007-2013, project no. POSDRU/159/1.5/136893.

\section{REFERENCES}

1. Aurich C and Schneider J (2014). Sex determination in horses - Current status and future perspectives. Animal Reproduction Science 146: 34-41.

2. Cenariu M, Groza I, Pall E, Bogdan L, Morar I and Pop R (2011). Sexing of bovine embryos using polymerase chain reaction (PCR) and fluorescent in situ hybridization (FISH). Romanian Biotechnological letters 16 (2): 60566061.

3. Cenariu M (2012): Biotehnologia sexării embrionilor și fetusilor bovini. Ed. Academic press, Cluj-Napoca, 1-45.

4. Chezum B and Wimmer B (1997). Roses or lemons: adverse selection in market for Thoroughbred yearlings. Rev. Econ. Stat. 79: 521-526.

5. Choi YH, Gustafson-Seabury A, Velez IC, Hartman DL, Bliss S, Riera FL, Roldán JE, Chowdhary B and Hinrichs K (2010). Viability of equine embryos after puncture of the capsule and biopsy for preimplantation genetic diagnosis. Reproduction 140: 893-902.

6. Choi YH, Velez IC, Riera FL, Roldán JE, Hartman DL and Bliss SB (2011). Successful cryopreservation of expanded equine blastocysts. Theriogenology 76: 143-152.

7. Cullingford E (2010): Preimplantation genetic diagnosis of equine embryos. Master Thesis. Colorado State University.

8. Guignot F, Perreau C, Reigner F, Mermillod P and Duchamp $G$ (2012). Establishment of pregnancies after transfer of biopsied equine embryos. JEVS, 32: 402-403.

9. Herrera C, Ratti MC and Sporleder C (2012). A simple method for pre-implantation genetic gender diagnosis of biopsied equine embryos. ISAG Proc.:P5046
10. Herrera C, Morikawaa MI, Belloa MB, Meyerena M, Eusebio Centenoa J, Dufourqa P, Martinez MM and Llorentea J (2014). Setting up equine embryo gender determination by preimplantation genetic diagnosis in a commercial embryo transfer program. Theriogenology 81 (5): 758763.

11. Huhtinen M, Peippo J and Bredbacka P (1997). Successful transfer of biopsied equine embryos. Theriogenology 48: 361-367. doi: http://dx.doi.org/10.1016/S0093691X(97)00247-1.

12. Jarazo J, Gambini A, Muredas L, Fernandez-Martin R, Salamone D (2013). Horse embryo biopsy: effect on pregnancy rates and successful sex determination depending on the size of the embryo. Reprod. Fertil. Dev. 25: 224

13. Mara L, Pilichi S, Sanna A, Accardo C, Chessa B, Chessa F, Dattena M, Bomboi G and Cappai P (2004). Sexing of in vitro produced ovine embryos by duplex PCR. Mol. Reprod. Dev. 69: 35-42.

14. Panarace M, Pellegrini RO, Basualdo MO, Belé M, Ursino DA, Cisterna R, Desimone G, Rodríguez E and Medina MJ (2013). First field results on the use of stallion sexsorted semen in a large-scale embryo transfer program. Theriogenology 81(4): 520-525.

15. Riera LF, Roldán JE, Grunwaldt M, Velez IC, Choi YH and Hinrichs K (2012). From commercial embryo transfer to assisted reproduction technology. JEVS 32: 404.

16. Seidel GE, Cullingford EL, Stokes JE, Carnevale EM and McCue PM (2010). Pregnancy rates following transfer of biopsied and/or vitrified equine embryos: evaluation of two biopsy techniques. Anim. Reprod. Sci., 121S: 297-298.

17. Stroud B (2012). The year 2011 worldwide statistics of embryo transfer in domestic farm animals. In: IETS Annual Report 2012. IETS, Champaign, Illinois, USA, http://www. iets.org/pdf/Newsletter/ Dec12IETS Newsletter.pdf.

18. Troedsson MHT., Paprocki AM, Koppang RW, Syverson CM, Griffin P and Klein C (2010). Transfer success of biopsied and vitrified equine embryos. Anim. Reprod. Sci., 121 (Suppl. 1): S295-S296. 